\title{
Taxonomic Relationship of Black-Pigmented Bacillus subtilis Strains and a Proposal for Bacillus atrophaeus sp. nov.
}

\author{
L. K. NAKAMURA \\ Northern Regional Research Center, Peoria, Illinois 61604
}

\begin{abstract}
The taxonomic position of Bacillus subtilis strains that produce soluble black pigment is unclear. To assess the genetic relatedness between the pigmented and nonpigmented strains, deoxyribonucleic acid (DNA) reassociation was measured spectrophotometrically. Among the 40 pigmented strains examined, two distinct DNA relatedness groups were found. A total of 25 strains (group 1) showed 24 to $34 \%$ DNA relatedness and 15 strains (group 2) showed 70 to $100 \%$ relatedness to Bacillus subtilis type strain NRRL NRS-744. The intragroup DNA relatedness values for each group ranged from 85 to $100 \%$; the intergroup relatedness values ranged from 20 to $35 \%$. A multilocus enzyme electrophoresis analysis revealed a low level of similarity between group 1 and group 2 or the nonpigmented group. The group 2 strains and the nonpigmented strains clustered in a common group, indicating the close genetic relationship of these organisms. My results strongly suggest that group 2 is a pigmented variant of $B$. subtilis, but group 1 is a new species, for which the name Bacillus atrophaeus is proposed. The type strain of the new species is strain NRRL NRS-213.
\end{abstract}

Smith et al. (13) observed and studied two black-pigmented varieties of Bacillus subtilis. One variety, designated "Bacillus subtilis var. aterrimus,", developed a soluble black pigment in media containing glucose or other utilizable carbohydrates; the other, called "Bacillus subtilis var. niger," formed a soluble dark pigment in tyrosine-containing media. Early workers presumed that pigmentation in " $B$. subtilis var. niger' resulted from tyrosinase activity. Because it was repeatedly observable in the crude agar media available to Smith et al. (13), black-pigment development was considered to be a stable characteristic and, therefore, a dependable and distinctive basis for varietal designation.

Some black-pigmented $B$. subtilis strains have important uses or characteristics. For example, "B. subtilis var. niger" strains produce 1-deoxynojirimycin, a substance with antibiotic as well as glucosidase-inhibiting activities (10). Selected "B. subtilis var. niger" strains are also used as standards for autoclave sterility testing (Catalogue of Bacteria, Phages, and rRNA Vectors, 16th ed., American Type Culture Collection, Rockville, Md.).

Except for pigment production, the colored strains are generally phenotypically indistinguishable from nonpigmented $B$. subtilis strains. However, in an extensive numerical phenetic survey carried out by Priest et al. (8), B. subtilis and " $B$. subtilis var. niger" did segregate into distinct but adjacent clusters. Furthermore, studies based on a small number of strains have indicated that strains classified as " $B$. subtilis var. aterriums" are genetically unrelated to strains classified as " $B$. subtilis var. niger' (2). In this study I augmented the sparse previously existing taxonomic data with guanine-plus-cytosine $(\mathrm{G}+\mathrm{C})$ and deoxyribonucleic acid (DNA) relatedness measurements and with enzyme electrophoresis pattern analyses of 40 black-pigmented and 12 nonpigmented strains identified as $B$. subtilis.

\section{MATERIALS AND METHODS}

Bacterial strains. Table 1 lists the pigmented and nonpigmented $B$. subtilis strains used in this study. Also used in this study were Bacillus alvei Cheshire and Cheyne 1885 NRRL B-383 ${ }^{\mathrm{T}}$ ( $\mathrm{T}=$ type strain), Bacillus badius Batchelor 1919 NRRL NRS-663 ${ }^{\mathrm{T}}$, Bacillus brevis Migula 1900 NRRL NRS$604^{\mathrm{T}}$, Bacillus coagulans Hammer 1915 NRRL NRS-609 ${ }^{\mathrm{T}}$, Bacillus firmus Bredemann and Werner 1933 NRRL B-
$14307^{\mathrm{T}}$, Bacillus licheniformis (Weigmann) Chester 1901 NRRL NRS-1264 ${ }^{\mathbf{T}}$, Bacillus polymyxa (Prazmowski) Mace 1889 NRRL NRS-1105 ${ }^{\mathrm{T}}$, and Bacillus pumilus Meyer and Gottheil 1901 NRRL NRS-272 ${ }^{\mathrm{T}}$. The Northern Regional Research Laboratory (NRRL) strain designations include the prefixes B- and NRS-; the prefix B- indicates strains that were obtained directly from a source or strains that were isolated at the Northern Regional Research Center, and the prefix NRS- indicates strains that were obtained from N. R. Smith. Working cultures were grown at $30^{\circ} \mathrm{C}$ in soil extract agar (5) until sporulation occurred, and they were stored at $4^{\circ} \mathrm{C}$.

DNA investigations. The cells were grown in TGY broth (6) with agitation and were harvested by centrifugation at $5^{\circ} \mathrm{C}$ in the mid- or late logarithmic growth phase. All cultures were checked microscopically for the absence of sporulation before harvesting. Previous publications have described the procedure used for preparing highly purified DNA samples by hydroxyapatite chromatography and the method used for measuring the extent of DNA reassociation by determining DNA renaturation rates spectrophotometrically with a model 250 ultraviolet spectrophotometer (Gilford Instrument Laboratories, Inc., Oberlin, Ohio) equipped with a model 2527 thermoprogramer (7). The equation of De Ley et al. (3) was used to calculate DNA relatedness values.

The $\mathrm{G}+\mathrm{C}$ contents of DNA samples were determined by measuring buoyant densities by $\mathrm{CsCl}$ density centrifugation in a Beckman model E ultracentrifuge (9). Micrococcus luteus (synonym, "Micrococcus lysodeikticus") DNA with a buoyant density of $1.724 \mathrm{~g} / \mathrm{cm}^{3}$, which was purchased from Sigma Chemical Co., St. Louis, Mo., was used as an internal standard.

Characterization. The physiological, morphological, and biochemical characteristics were determined as described previously $(5,7)$.

Enzyme electrophoresis. Cells were grown at $30^{\circ} \mathrm{C}$ for $24 \mathrm{~h}$ in 3 liters of TGY broth with agitation, harvested by centrifugation at $30,000 \times \mathrm{g}$ for $10 \mathrm{~min}$, and suspended in $10 \mathrm{ml}$ of pH 6.8 buffer containing $10 \mathrm{mM}$ tris (hydroxymethyl) aminomethane (Tris), $1 \mathrm{mM}$ ethylenediaminetetraacetate, and $0.5 \mathrm{mM} \mathrm{NaH}\left(\mathrm{PO}_{4}\right)_{2}$. The cells were disrupted by passage through a chilled French pressure cell at $10,000 \mathrm{lb} / \mathrm{in}^{2}$. After centrifugation at $30,000 \times g$ for $15 \mathrm{~min}$ at $4^{\circ} \mathrm{C}$, portions of the 
TABLE 1. List of $B$. subtilis strains used in this study

\begin{tabular}{|c|c|c|c|}
\hline NRRL no. & Received as strain(s): & Source ${ }^{a}$ & Strain history ${ }^{b}$ \\
\hline B-357 & NRS-242 & 1 & From soil \\
\hline B-360 & NRS-230 & 1 & C. Thom, from corn \\
\hline B-361 & NRS-259 & 1 & I. C. Hall \\
\hline B-362 & NRS-624 & 1 & J. R. Porter from F. W. Fabian \\
\hline B-363 & NRS-212 & 1 & From Colorado soil \\
\hline B-364 & NRS-220 & 1 & AMNH from Kral Collection \\
\hline B-365 & NRS-356 & 1 & "B. subtilis var. niger"c \\
\hline B-447 & 20 & 2 & "Bacillus mesentericus" \\
\hline B-554 & $12-\mathrm{H}$ & 3 & \\
\hline B-627 & & 4 & "B. subtilis var. niger" \\
\hline B-765 & ATCC 6633 & 5 & N. R. Smith 231 from K. F. Kellerman \\
\hline B-971 & 398 & 6 & \\
\hline B-4418 & GL 100 & 7 & "B. subtilis subsp. niger" \\
\hline NRS-162 & NRS-162 & 1 & D. M. Webley FFT, from grass compost \\
\hline NRS-163 & NRS-163 & 1 & D. M. Webley HFT, from grass compost \\
\hline NRS-193 & NRS-193 & 1 & W. Bohrer, C-1889, from okra \\
\hline $\begin{array}{l}\text { NRS-211, NRS-213 }{ }^{\mathrm{T}}, \text { NRS-214 to } \\
\text { NRS-216, NRS-218, NRS-219, } \\
\text { NRS-221 to NRS-224, NRS-226 } \\
\text { to NRS-228 }\end{array}$ & $\begin{array}{l}\text { NRS-211, NRS-213 }{ }^{\mathrm{T}} \text {, NRS-214 to } \\
\text { NRS-216, NRS-218, NRS-219, } \\
\text { NRS-221 to NRS-224, NRS-226 } \\
\text { to NRS-228 }\end{array}$ & 1 & $\begin{array}{l}\text { N. R. Smith, "B. subtilis var. niger," from } \\
\text { Colorado soil }\end{array}$ \\
\hline NRS-229 & NRS-229 & & $\begin{array}{l}\text { N. R. Smith, "B. subtilis var. niger," from Utah } \\
\text { soil }\end{array}$ \\
\hline NRS-253 & NRS-253 & & N. R. Smith, "B. subtilis var. niger,” from air \\
\hline NRS-261, NRS-262 & NRS-261, NRS-262 & 1 & $\begin{array}{l}\text { I. C. Hall } 620 \text {, I. C. Hall } 621 \mathrm{~A}, \text { "B. subtilis var. } \\
\text { aterrimus" }\end{array}$ \\
\hline NRS-263 & NRS-263 & 1 & $\begin{array}{l}\text { I. C. Hall 798B from W. W. Ford, "Bacillus } \\
\text { aterrimus" }\end{array}$ \\
\hline NRS-264 & NRS-264 & 1 & $\begin{array}{l}\text { I. C. Hall 799, "Bacillus niger," from W. W. } \\
\text { Ford from Kral collection }\end{array}$ \\
\hline NRS-265 & NRS-265 & 1 & I. C. Hall 1509, (ATCC 6455) ${ }^{d}$ \\
\hline NRS-274 & NRS-274 & 1 & USDA, from air \\
\hline NRS-275 & NRS-275 & 1 & USDA, from Maryland soil, (ATCC 6461) \\
\hline NRS-276 & NRS-276 & 1 & USDA, from Maryland soil \\
\hline NRS-330 & NRS-330 & 1 & $\begin{array}{l}\text { NCTC 2590, “Bacillus aterrimus," from W. W. } \\
\text { Ford 5A }\end{array}$ \\
\hline NRS-561 & NRS-561 & 1 & NIH 4 \\
\hline NRS-651 & NRS-651 & 1 & $\begin{array}{l}\text { NCA, "Bacillus niger," from R. S. Breed from } \\
\text { NCTC 2592, from W. W. Ford } 6\end{array}$ \\
\hline NRS-652 & NRS-652 & 1 & $\begin{array}{l}\text { NCA, "Bacillus aterrimus," from R. S. Breed } \\
\text { from NCTC } 2590 \text { from W. W. Ford 5A }\end{array}$ \\
\hline NRS-653 & NRS-653 & 1 & $\begin{array}{l}\text { NCA, "Bacillus aterrimus," from R. S. Breed } \\
\text { from NCTC } 2591 \text { from W. W. Ford 5B }\end{array}$ \\
\hline NRS-655 & NRS-655 & 1 & $\begin{array}{l}\text { NCA, "Bacillus lactis niger," from R. S. Breed } \\
\text { from C. Gorini } 2\end{array}$ \\
\hline NRS-704 & NRS-704 & 1 & M. L. Rakieten C3, “B. subtilis (niger)" \\
\hline NRS-730 & NRS-730 & 1 & $\begin{array}{l}\text { ATCC 7003, “Bacillus graveolens," from F. S. } \\
\text { Orcutt }\end{array}$ \\
\hline NRS-740 & NRS-740 & 1 & $\begin{array}{l}\text { ATCC } 4295, \text { "Bacillus nigrificans," from F. W. } \\
\text { Fabian from pickle brine }\end{array}$ \\
\hline NRS-744 & NRS- $744^{\mathrm{T}}$ & 1 & ATCC $6051^{\mathrm{T}}$ from H. J. Conn from NCTC $3610^{\mathrm{T}}$ \\
\hline NRS-748 & NRS-748 & 1 & USDA, from decomposed wheat \\
\hline
\end{tabular}

${ }^{a}$ 1, N. R. Smith, U. S. Department of Agriculture Research Center, Beltsville, Md.; 2, C. E. Georgi, University of Nebraska, Lincoln; 3, J. Naghski, Eastern Regional Research Laboratory, Chestnut Hill, Pa.; 4, L. J. Wickerham, Northern Regional Research Laboratory, Peoria, Ill.: 5, American Type Culture Collection, Rockville, Md.; 6, P. Stansly, American Cyanamid Co., Pearl River, N.Y.; 7, R. Gillis, Amsco Co., Erie Pa.

${ }^{b}$ AMNH, American Museum of Natural History, Washington, D.C.; ATCC, American Type Culture Collection, Rockville, Md.; USDA United States Department of Agriculture, Washington, D.C.; NCTC, National Collection of Type Cultures, London, England; NIH, National Institutes of Health, Washington, D.C.; NCA, National Canners Association, San Francisco, Calif.

${ }^{c}$ Names in quotation marks are not on the Approved Lists of Bacterial Names (12) and have not been validly published since January 1980.

${ }^{d}$ Designations in parentheses are equivalent strain designations.

supernatant were transferred to capped, 1-ml plastic centrifuge tubes and stored at $-20^{\circ} \mathrm{C}$. Fresh cell lysates were prepared at weekly intervals.

Enzymes were separated by vertical electrophoresis through polyacrylamide slab gels $(0.75 \mathrm{~mm}$ by $15.5 \mathrm{~cm}$ by 16 $\mathrm{cm})$. A stacking gel $(0.75 \mathrm{~mm}$ by $4.5 \mathrm{~cm}$ by $16 \mathrm{~cm})$ was also used. The separating gel $(12 \%)$ contained $11.68 \%$ acrylamide, $0.32 \% N, N^{\prime}$-methylene bisacrylamide, $0.05 \%$ ammo- nium persulfate, and $0.05 \% \quad N, N, N^{\prime}, N^{\prime}$-tetramethylethylenediamine. The stacking gel $(4 \%)$ contained $3.9 \%$ acrylamide, $0.1 \% \quad N, N^{\prime}$-methylene bisacrylamide, $0.05 \%$ ammonium persulfate, and $0.1 \% N, N, N^{\prime}, N^{\prime}$-tetramethylethylenediamine. The separating gel buffer was $0.375 \mathrm{M}$ Tris hydrochloride ( $\mathrm{pH} 8.8$ ), and the stacking gel buffer was 0.125 M Tris hydrochloride ( $\mathrm{pH} 6.8$ ). The running buffer ( $\mathrm{pH} 8.3$ ) was a mixture of $0.123 \mathrm{M}$ Tris and $0.959 \mathrm{M}$ glycine. Electro- 
TABLE 2. DNA relatedness of pigmented B. subtilis strains

\begin{tabular}{|c|c|c|c|c|c|}
\hline \multirow{2}{*}{$\begin{array}{c}\text { Strain } \\
\text { (NRRL no.) }\end{array}$} & \multicolumn{3}{|c|}{$\%$ Reassociation with DNA from $\operatorname{strain}^{a}$ : } & \multicolumn{2}{|c|}{ Soluble pigment color on $^{b}$ : } \\
\hline & $\begin{array}{c}\text { NRRL } \\
\text { NRS-213 }\end{array}$ & $\begin{array}{c}\text { NRRL } \\
\text { NRS-261 }\end{array}$ & $\begin{array}{c}\text { NRRL } \\
\text { NRS-744T }\end{array}$ & TGY agar & $\begin{array}{l}\text { Glycerol- } \\
\text { glutamate agar }\end{array}$ \\
\hline \multicolumn{6}{|l|}{ Group 1} \\
\hline B-363 & 97 & 29 & 35 & Brownish black & Brown \\
\hline B-364 & 95 & 28 & 27 & Brownish black & Brown \\
\hline B-365 & 93 & 27 & 25 & Brownish black & Brown \\
\hline B-627 & 90 & 33 & 35 & Brownish black & Brown \\
\hline B-4418 & 98 & 34 & 27 & Brownish black & Brown \\
\hline NRS-211 & 88 & 27 & 25 & Brownish black & Brown \\
\hline NRS $-213^{\mathrm{T}}$ & $(100)^{c}$ & 24 & 30 & Brownish black & Brown \\
\hline NRS-214 & 100 & 26 & 25 & Brownish black & Brown \\
\hline NRS-215 & 100 & 29 & 23 & Brownish black & Brown \\
\hline NRS-216 & 94 & 26 & 30 & Brownish black & Brown \\
\hline NRS-218 & 94 & 33 & 29 & Brownish black & Brown \\
\hline NRS-219 & 91 & 27 & 30 & Brownish black & Brown \\
\hline NRS-221 & 99 & 24 & 25 & Brownish black & Brown \\
\hline NRS-222 & 97 & 26 & 22 & Brownish black & Brown \\
\hline NRS-223 & 91 & 29 & 30 & Brownish black & Brown \\
\hline NRS-224 & 98 & 26 & 36 & Brownish black & Brown \\
\hline NRS-226 & 100 & 34 & 25 & Brownish black & Brown \\
\hline NRS-227 & 96 & 32 & 32 & Brownish black & Brown \\
\hline NRS-228 & 96 & 28 & 32 & Brownish black & Brown \\
\hline NRS-229 & 91 & 30 & 25 & Brownish black & Brown \\
\hline NRS-253 & 96 & 26 & 33 & Brownish black & Brown \\
\hline NRS-265 & 94 & 31 & 27 & Brownish black & Brown \\
\hline NRS-651 & 88 & 30 & 30 & Brownish black & Brown \\
\hline NRS-704 & 96 & 24 & 30 & Brownish black & Brown \\
\hline NRS-748 & 92 & 29 & 25 & Brownish black & Brown \\
\hline \multicolumn{6}{|l|}{ Group 2} \\
\hline B-360 & 20 & 100 & 96 & Brown & Bluish black \\
\hline B-361 & 29 & 100 & 93 & Brown & Bluish black \\
\hline B-362 & 25 & 100 & 96 & Brown & Bluish black \\
\hline NRS-261 & 25 & $(100)$ & 96 & Brown & Bluish black \\
\hline NRS-262 & 30 & 84 & 92 & Brown & Bluish black \\
\hline NRS-263 & 24 & 93 & 99 & Brown & Bluish black \\
\hline NRS-264 & 21 & 95 & 100 & Brown & Bluish black \\
\hline NRS-274 & 23 & 98 & 100 & Brown & Bluish black \\
\hline NRS-275 & 25 & 90 & 85 & Brown & Bluish black \\
\hline NRS-276 & 26 & 93 & 92 & Brown & Bluish black \\
\hline NRS-330 & 35 & 99 & 98 & Brown & Bluish black \\
\hline NRS-652 & 27 & 100 & 98 & Brown & Bluish black \\
\hline NRS-653 & 27 & 90 & 97 & Brown & Bluish black \\
\hline NRS-655 & 29 & 99 & 70 & Brown & Bluish black \\
\hline NRS-740 & 30 & 90 & 95 & Brown & Bluish black \\
\hline \multicolumn{6}{|l|}{ Group 3} \\
\hline B-357 & 25 & 100 & 100 & None & None \\
\hline B-447 & 23 & 100 & 98 & None & None \\
\hline B-554 & 30 & 100 & 93 & None & None \\
\hline B-765 & 30 & 75 & 89 & None & None \\
\hline B-971 & 28 & 80 & 70 & None & None \\
\hline NRS-161 & 25 & 91 & 92 & None & None \\
\hline NRS-162 & 30 & 96 & 95 & None & None \\
\hline NRS-163 & 28 & 100 & 91 & None & None \\
\hline NRS-193 & 36 & 94 & 88 & None & None \\
\hline NRS-561 & 33 & 93 & 100 & None & None \\
\hline NRS-730 & 22 & 95 & 98 & None & None \\
\hline NRS- $744^{\mathrm{T}}$ & 30 & 96 & $(100)$ & None & None \\
\hline
\end{tabular}

" Reassociation values are averages of two determinations; the maximum difference found between determinations was $7 \%$.

$b$ Brownish black pigmentation of group 1 strains was observed after 2 to 6 days in TGY agar, and brown pigmentation of group 2 strains was observed after 14 days. Brown pigmentation of group 1 strains in glycerol-glutamate agar was observed after 6 to 13 days, and bluish black pigmentation of group 2 strains was observed after 1 to 2 days.

${ }^{c}$ Values in parentheses indicate that, by definition, the reassociation value was $100 \%$.

phoresis was carried out at $5^{\circ} \mathrm{C}$ at a constant amperage of 13 $\mathrm{mA}$ per slab to stack the samples and $18 \mathrm{~mA}$ per slab to effect enzyme separation. Sample proteins were diluted to a concentration of $600 \mu \mathrm{g} / \mathrm{ml}$ in $0.125 \mathrm{M}$ Tris hydrochloride $(\mathrm{pH}$ 6.8) containing $10 \%$ glycerol and $0.00125 \%$ bromophenol blue; $50-\mu l$ portions of the diluted samples were analyzed electrophoretically.

The 12 enzymes studied were alanine dehydrogenase (EC 1.4.1.1), alcohol dehydrogenase (EC 1.1.1.1), aspartate dehydrogenase (EC 1.4.3. $\times$ ), fumarase (EC 4.2.1.2), glucose- 
TABLE 3. Levels of DNA relatedness of group reference strains and selected Bacillus spp. type strains

\begin{tabular}{|c|c|c|c|}
\hline \multirow{2}{*}{ Strain } & \multirow{2}{*}{$\begin{array}{c}\mathrm{G}+\mathrm{C} \\
\text { content } \\
(\mathrm{mol} \%)^{a}\end{array}$} & \multicolumn{2}{|c|}{$\begin{array}{l}\text { \% Reassociation with } \\
\text { DNA from group } \\
\text { reference } \text { strain }^{b} \text { : }\end{array}$} \\
\hline & & $\begin{array}{c}\text { NRRL } \\
\text { NRS-213 }\end{array}$ & $\begin{array}{c}\text { NRRL } \\
\text { NRS-261 }\end{array}$ \\
\hline B. firmus NRRL B-14307 ${ }^{\mathrm{T}}$ & 41.5 & 27 & 23 \\
\hline B. pumilus NRRL NRS- $272^{\mathrm{T}}$ & 42.0 & 17 & 24 \\
\hline B. badius NRRL NRS- $663^{\mathrm{T}}$ & 43.8 & 26 & 30 \\
\hline B. polymyxa NRRL NRS-1105 & 44.5 & 37 & 23 \\
\hline B. alvei NRRL B-383 & 44.6 & 29 & 32 \\
\hline B. coagulans NRRL NRS $-609^{\mathrm{T}}$ & 45.0 & 29 & 25 \\
\hline B. licheniformis NRRL NRS-1264 & 46.5 & 21 & 22 \\
\hline B. brevis NRRL NRS-604 ${ }^{\mathrm{T}}$ & 47.5 & 28 & 30 \\
\hline
\end{tabular}

${ }^{a}$ Data from reference 4

$b$ Reassociation values are averages of two determinations; the maximum difference found between determinations was $7 \%$.

6-phosphate dehydrogenase (EC 1.1.1.49), glutamate dehydrogenase (EC 1.4.1.2), hexokinase (EC 2.7.1.1), indophenol oxidase (EC 1.15.1.1), leucine dehydrogenase (EC 1.4.3.2), lysine dehydrogenase (EC 1.4.3. $\times$ ), malic dehydrogenase (EC 1.1.1.40), and phosphoglucose isomerase (EC 5.3.1.9). The enzymes were stained by using the method of Selander et al. (11).

The relative mobilities of alternative forms of each enzyme in the strains were compared directly on the electrophoresis gels. These allozymes (electromorphs) were assumed to be encoded by chromosomal genes and thus were equated with alleles at each locus. The electromorphs were numbered in order of increasing anodal mobility, and the combination of electromorphs at the 12 enzyme loci was determined for each strain. The absence of enzyme activity was scored as a null allele. Each distinctive combination of alleles was designated an electrophoretic type (ET).

Levels of similarity among strains were determined by using the simple matching coefficient, and clustering was based on the unweighted pair group arithmetic average algorithm (14). Computations were carried with an DTK AT computer by using the TAXAN program of David Swartz, University of Maryland, College Park.

\section{RESULTS}

B. subtilis strains that produced a soluble black pigment segregated into two groups on the basis of DNA relatedness (Table 2). Group 1 strains (which produced a brownish black pigment) showed 88 to $100 \%$ DNA relatedness to reference strain NRRL NRS- $213^{\mathrm{T}}$ and a range of relatedness to reference strains NRRL NRS-261 (which produced a bluish black pigment) and NRRL NRS-744 ${ }^{\mathrm{T}}$ (nonpigmented) of 22 to $35 \%$. Strains in group 2 (which produced a bluish black pigment) had levels of DNA complementarity of 84 to 100 and 70 to $100 \%$ with reference strains NRRL NRS-261 and NRRL NRS-744 ${ }^{\mathrm{T}}$, respectively. The levels of DNA relatedness of group 2 strains to strain NRRL NRS- $213^{\mathrm{T}}$ ranged from 20 to $35 \%$. The nonpigmented group 3 strains showed 70 to $100 \%$ DNA relatedness to reference strain NRRL NRS- $744^{\mathrm{T}}$ and 75 to $100 \%$ DNA relatedness to strain NRRL NRS-261. The levels of DNA relatedness between group 3 strains and strain NRRL NRS-213 ${ }^{\mathrm{T}}$ ranged from 22 to $36 \%$. The intragroup DNA relatedness values (data not shown) for all three groups ranged from 85 to $100 \%$.

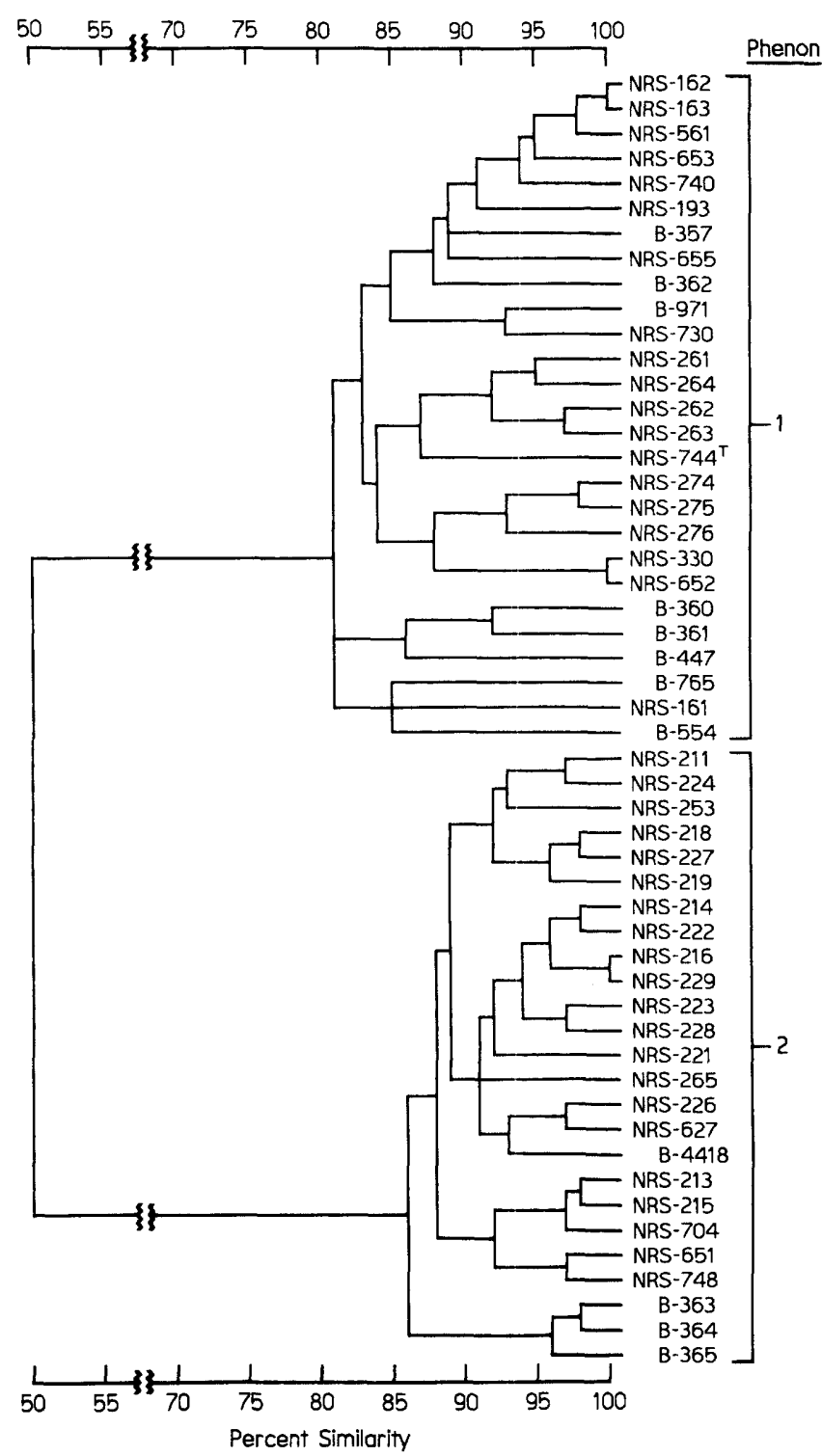

FIG. 1. Relationships of pigmented B. subtilis strains. The dendrogram was generated by unweighted average linkage clustering from a matrix of simple matching coefficients based on 12 enzyme loci.

The data in Table 3 show that reference strains NRRL NRS-213 ${ }^{\mathrm{T}}$ and NRRL NRS-261 yielded low DNA complementarity values ( 17 to $37 \%$ ) with the following type strains: B. alvei NRRL B-383, B. badius NRRL NRS-663, B. brevis NRRL NRS-604, B. coagulans NRRL NRS-609, B. firmus NRRL B-14307, B. licheniformis NRRL NRS-1264, B. polymyxa NRRL NRS-1105, and $B$. pumilus NRRL NRS-272. These species had $G+C$ contents ranging from 40.5 to 47.5 mol\%, a range that includes the values (41 to $43 \mathrm{~mol} \%$ ) exhibited by the pigmented strains.

Analyses of the multilocus enzyme electrophoresis data revealed 49 ETs. The overall genetic diversity (11) of the 49 ETs was 0.39 . The dendrogram in Fig. 1 shows the relationships of ETs based on the enzyme electrophoresis data. At a level of about $50 \%$ similarity, two distinct phena were identified. Phenon 1 , with a genetic diversity of 0.3 , contained 27 strains that represented 25 ETs ( 2 ETs contained 
two strains each; the other ETs were one-member entities). Within this phenon, two enzymes were monomorphic, and 10 were polymorphic. The strains included in this phenon correspond exactly to the strains in DNA relatedness groups 2 and 3 . Phenon 2 , with a genetic diversity of 0.27 , contained 25 strains that were equivalent to 24 ETs ( 1 ET contained two strains, and the other ETs contained one strain each). The strains in this phenon were identical to the strains found in DNA relatedness group 1 . Of 12 enzymes, 4 were monomorphic and 8 were polymorphic.

Except for the color of the soluble pigment, all of the strains were indistinguishable by the standard characterization method (data not shown); i.e., they exhibited the traits typical of $B$. subtilis (5). The $\mathrm{G}+\mathrm{C}$ contents of all of the strains ranged from 41 to $43 \mathrm{~mol} \%$. All group 1 strains produced a soluble brownish black pigment in 2 to 6 days in TGY agar (5); group 2 strains produced a brown pigment slowly in TGY agar. On the glycerol-glutamate medium of Arai and Mikami (1), group 2 strains synthesized a distinctly blue pigment in 1 to 2 days, the color of which intensified to a bluish black hue after 6 days. Group 1 strains produced only a brown pigment in glycerol-glutamate agar in 6 to 13 days.

\section{DISCUSSION}

The results of DNA relatedness studies indicate that the soluble pigment-forming strains of $B$. subtilis consist of two distinct genetically unrelated groups. Low DNA relatedness values show that the producers of the brownish black pigment are genetically unrelated to the bluish black strains and the nonpigmented strains. Moreover, the brownish black-pigmented organisms are also not closely related genetically to previously described species with $\mathrm{G}+\mathrm{C}$ contents ranging from about 40 to $48 \mathrm{~mol} \%$ (Table 3 ). Thus, the brownish black pigment producers, once classified as " $B$. subtilis var. niger," are members of a separate species. High DNA relatedness levels indicate that the bluish black pigment producers and nonpigmented $B$. subtilis strains are closely related genetically and thus are cospecific. Thus, the bluish black-pigmented strains are truly variants of $B$. subtilis.

The results of multilocus enzyme electrophoresis analyses supported the conclusions drawn from the DNA relatedness studies. Basically, the reduction of the genetic diversity value from 0.39 to about 0.30 upon segregation into the brownish black- and bluish black-pigmented groups suggested genetic heterogeneity of the whole group. If the group were genetically homogeneous, subgrouping should not have affected the genetic diversity value. Furthermore, organisms that form tight DNA relatedness groups are closely related on the basis of enzyme electrophoresis comparisons. While subgroups occur in phenon 1 at the 84 to $85 \%$ similarity level, the blue-pigmented strains are dispersed in a roughly even pattern among these subgroups. This suggests that mutations causing blue pigmentation occurred independently of mutations causing allelic enzyme variation.

Although conventional classification procedures barely differentiate one pigmented group from the other, DNA relatedness and multilocus enzyme electrophoresis analyses have established clearly that the $B$. subtilis-like organisms which produce a soluble brownish black pigment are members of a distinct, previously unnamed species. Since it is phenotypically virtually identical to $B$. subtilis, the pigmented taxon can be differentiated from $B$. alvei, $B$. badius, $B$. brevis, B. coagulans, B. firmus, B. licheniformis, $B$. polymyxa, and $B$. pumilus on the same bases as $B$. subtilis is. These brownish black pigment producers represent between 10 and $15 \%$ of the 300 organisms identified as B. subtilis in the Agricultural Research Service Culture Collection. Based on their demonstrated distinctiveness, rather common occurrence in nature, and usefulness, these organisms merit designation as members of a new species, for which I propose the name Bacillus atrophaeus. A description of the species is given below.

Bacillus atrophaeus sp. nov. Bacillus atrophaeus (a.tro.phae'.us L. adj. ater, black; Gr. adj. phaeus, brown; M.L. adj. atrophaeus, dark brown) vegetative cells are rods that are 0.5 to $1.0 \mu \mathrm{m}$ wide by 2.0 to $4.0 \mu \mathrm{m}$ long (as determined by phase microscopy) and occur singly and in short chains. Motile. Gram positive. Produces ellipsoidal spores centrally or paracentrally in unswollen sporangia.

Agar colonies are opaque, smooth, circular, entire, and 1.0 to $2.0 \mathrm{~mm}$ in diameter after 2 days at $28^{\circ} \mathrm{C}$. A dark brown pigment is formed in 2 to 6 days in media containing an organic nitrogen source.

Catalase is produced. Oxidase is not produced. Aerobic. Acetylmethylcarbinol (Voges-Proskauer test) is produced. Hydrogen sulfide, indole, and dihydroxyacetone are not produced. The $\mathrm{pH}$ in Voges-Proskauer broth ranges from 5.3 to 5.7. Nitrate is reduced to nitrite. Starch and casein are hydrolyzed. Citrate but not propionate is utilized. Egg yolk lecithin, Tween 80 , and urea are not decomposed. The $\mathrm{pH}$ in litmus milk is alkaline; casein is digested.

Arginine, lysine, ornithine, phenylalanine, and tyrosine are not decomposed.

The optimum growth temperature ranges from 28 to $30^{\circ} \mathrm{C}$, the maximum growth temperature ranges from 50 to $55^{\circ} \mathrm{C}$, and the minimum growth temperature ranges from 5 to $10^{\circ} \mathrm{C}$. Grows at $\mathrm{pH} 5.6$ or 5.7 and in the presence of $7 \% \mathrm{NaCl}$. Growth is usually inhibited by $0.001 \%$ lysozyme.

Acid but no gas is produced from $\mathrm{L}$-arabinose, D-fructose, D-glucose, mannitol, salicin, sucrose, trehalose, and Dxylose. Acid production from cellobiose, D-galactose, maltose, D-mannose, D-ribose, L-rhamnose, and sorbitol is variable. Lactose and melibiose are not fermented.

The DNA buoyant density ranges from 1.6946 to 1.6966 $\mathrm{g} / \mathrm{cm}^{3}$, and the $\mathrm{G}+\mathrm{C}$ contents determined from these values are 41 to $43 \mathrm{~mol} \%$.

The description above is virtually identical to that of $B$. subtilis. The new species is differentiated from $B$. subtilis on the basis of DNA relatedness and multilocus enzyme electrophoresis analyses, as well as pigment production.

Isolated mainly from soil.

The type strain is strain NRS-213, which has been deposited as NRRL NRS-213 in the Agricultural Research Service Culture Collection, Peoria, Ill.

\section{LITERATURE CITED}

1. Arai, T., and Y. Mikami. 1972. Chromogenicity of Streptomyces. Appl. Microbiol. 23:402-406.

2. Baptist, J. N., M. Mandel, and R. L. Gherna. 1978. Comparative zone electrophoresis of enzymes in the genus Bacillus. Int. J. Syst. Bacteriol. 28:229-244.

3. De Ley, J., H. Cattoir, and A. Reynaerts. 1970. The quantitative measurement of DNA hybridization from renaturation rates. Eur. J. Biochem. 12:133-142.

4. Fahmy, F., J. Flossdorf, and D. Claus. 1985. The DNA base composition of the type strains of the genus Bacillus. Syst. Appl. Microbiol. 6:60-65.

5. Gordon, R. E., W. C. Haynes, and C. H. Pang. 1973. The genus Bacillus. Agriculture Handbook No. 427. U.S. Department of 
Agriculture, Washington, D.C.

6. Haynes, W. C., L. J. Wickerham, and C. W. Hesseltine. 1955. Maintenance of cultures of industrially important microorganisms. Appl. Microbiol. 3:361-368.

7. Nakamura, L. K., and J. Swezey. 1983. Taxonomy of Bacillus circulans Jordon 1890: base composition and reassociation of deoxyribonucleic acid. Int. J. Syst. Bacteriol. 3:46-52.

8. Priest, F. G., M. Goodfellow, and C. Todd. 1988. A numerical classification of the genus Bacillus. J. Gen. Microbiol. 134: $1847-1882$.

9. Schildkraut, C. L., J. Marmur, and P. Doty. 1962. Determination of the base composition of deoxyribonucleic acid from its buoyant density in $\mathrm{CsCl}$. J. Mol. Biol. 4:430-443.

10. Schmidt, D. D., W. Frommer, L. Miller, and E. Truscheit. 1979.
Glucosidase-Inhibitoren aus Bazillen. Naturwissenschaften 66: 584-585.

11. Selander, R. K., D. A. Caugant, H. Ochman, J. M. Musser, M. N. Gilmour, and T. S. Whittman. 1986. Methods of multilocus enzyme electrophoresis for bacterial population genetics and systematics. Appl. Environ. Microbiol. 51:873-884.

12. Skerman, V. B. D., V. McGowan, and P. H. A. Sneath (ed.). 1980. Approved lists of bacterial names. Int. J. Syst. Bacteriol. 30:225-420.

13. Smith, N. R., R. E. Gordon, and F. E. Clark. 1946. Aerobic mesophilic sporeforming bacteria. Miscellaneous Publication No. 559. U.S. Department of Agriculture, Washington, D.C.

14. Sneath, P. H. A., and R. R. Sokal. 1973. Numerical taxonomy. W. H. Freeman and Co., San Francisco. 